\title{
Development of Electronic Metering Experimental Test Rig for Maize
}

\author{
C. Leela* and M. Saravanakumar \\ Department of Farm Machinery \& Power Engineering, (Agricultural Engineering College \& \\ Research Institute, Kumulur, Trichy-621712), India \\ *Corresponding author
}

\section{Keywords}

Microcontroller, Precision,

Proximity sensor, Solenoid

Article Info

Accepted:

12 July 2019

Available Online:

10 August 2019

\section{A B S T R A C T}

A simple laboratory test-rig for maize planter was developed for testing and calibrating the electronic seed metering mechanism. The test rig consists of two frame namely main frame and the second frame. The main frame consists of variable speed drive, electric motor and grease coated belt that are fitted with necessary provisions. The second frame consists of seed hopper, seed metering unit. The metering mechanism consists of a metering roll, seed delivery box with plunger plate, proximity sensor, solenoid valve to, $12 \mathrm{~V} \mathrm{DC}$ motor and the seed outlet pipe. The electronic control unit was designed with (555 timer) to assist the solenoid to move in to and fro movement being accomplished by action of spring. The developed electronic metering mechanism was tested in the laboratory test rig for maize seed at various forward speeds of $1.5,2$ and $2.5 \mathrm{~km} \mathrm{hr}^{-1}$. The seed to seed spacing and seed rate was calculated over grease coated belt and the results were statistically analyzed.

\section{Introduction}

Sowing is one of the most important operations in crop production, which requires precise placement of seed with recommended seed rate to maximize crop yield. Uniformity in seed dropping in row depends on the performance of planter seed metering rotor. Precision planting reduces seed scattering and excessive use of seeds by preventing seed from bouncing in the furrow which facilitates planter calibration on the basis of the number of seeds to be placed along a unit of the row
(Domier et al., 1991). Seed meter is the key component of precision planter and its performance affects the uniformity of seed distribution, directly. However, conventional planters are usually driven by ground wheel and power transmission is made through chain and sprocket. These mechanisms are of mechanical type and they use drive through gears or chains from the ground wheel. They are less efficient and exist to a number of losses while transmitting the power. Due to continuous friction between moving parts, these devices are subjected to wear and tear; 
hence they require frequent maintenance. To solve the above problems, an alternative power transmission method was identified by using electrical motor replacing mechanical driving system to drive seed meters. $\mathrm{CNH}$ and John Deere, the top two American agricultural machinery companies, have developed new technologies for driving seed meters of precision planter by using DC motors. Moreover, Singh et al., (2003) developed an electronically controlled metering mechanism for okra seed. Li et al., (2007) adapted stepper motor to drive seed meter and developed a control system based on Intel 8031 to control the planting process.

A wide variety of measures have been used to quantify seed drill performance with regard to seed spacing (Jasa et al., 1982); Kachman and Smith, (1995). Kocher et al., (1998) and Lan et al., (1999) developed an opto-electronic seed spacing evaluation systems that measure time intervals between the seeds and detect from the front to back location of seed spacing uniformity in the laboratory condition. The data obtained based on time intervals between seed drop were strongly correlated with the measurements obtained using greased belt test rig. Raheman and Singh (2003) developed a sensor based light interference technique for sensing the seed flow from the metering mechanism of seed drill and planter.

The assessment of plant spacing and seed rate as provided by the planters is also crucial in analyzing its performance. Variety of methods has been evolved to assess the performance of seed metering mechanism. Measuring the spacing between germinated plants after planting with machine is most common method. The accuracy of this method seriously affected by weather condition and more importantly by seed viability. The second most prevalently used method is the grease belt test rig under laboratory conditions, which is unaffected by crop, soil and weather conditions. Hence, this study was taken up to develop a test rig, and evaluate electronic seed metering mechanism by simulating planter operating conditions.

\section{Materials and Methods}

\section{Determination of physical properties of maize seed}

The physical properties of seed play an important role in seed singulation. Its properties viz., arithmetic mean diameter, sphericity, bulk density were determined by using standard procedure. The physical dimensions of the maize seeds were determined by selecting a group of 50 seeds, randomly. The length, breadth and thickness of the seeds were measured using vernier caliper with accuracy of $0.02 \mathrm{~mm}$. The thousand seed weight was determined by weighing thousand seeds of maize by means of an electronic weighing machine having an accuracy of $0.001 \mathrm{~g}$. Bulk density was measured taking the ratio of weight to volume of seed using a measuring cylinder. The results are shown in table 1 .

\section{Development of electronic metering mechanism}

An electronic based instrumentation system was developed based on the principle of optoelectronics. The metering unit consists of the hopper, metering roll, seed delivery box with plunger plate, proximity sensor which is used to detect the seed flow from the hopper, solenoid valve which is used to actuate the plunger plate, $12 \mathrm{~V} \mathrm{DC}$ motor is used to drive the metering roll shaft and the seed outlet pipe. An inverted pyramid shaped seed hopper was fabricated by using a MS sheet of $1.5 \mathrm{~mm}$ thickness. The top and bottom section of the seed hopper was maintained as $250 \times 250 \mathrm{~mm}$ and $35 \times 35 \mathrm{~mm}$, respectively. The seed delivery box along with plunger plate was 
made up of acrylic sheet with $4 \mathrm{~mm}$ thickness. A metering roller of diameter $35 \mathrm{~mm}$ with a cell of size $12 \mathrm{~mm}$ was accommodated at the bottom edge of the seed hopper to meter and agitate the seed.

The electronic device was designed with (555 timer) to assist the solenoid in the forth movement of the plunger plate and the back movement being accomplished by the action of spring. The seed flow was sensed by the proximity sensor which placed over the metering plate. The microcontroller was programmed in such a way so that the solenoid is actuated when the sensor receives signal (Fig. 1-6).

\section{Construction of a test rig}

A test rig was fabricated to study the effect of individual and interactive effect of the selected variables. It consist of main frame as a major component to which all other functional component viz., seed hopper, seed metering unit, variable speed drive, $12 \mathrm{~V}$ DC electric motor and grease coated belt are fitted. A rectangular main frame of size 3555 x $450 \mathrm{~mm}$ was fabricated using $50 \times 50 \times 6 \mathrm{~mm}$ MS "L" angle as shown in figure 5 . The second frame of size $800 \times 500 \mathrm{~mm}$ was fabricated using 50 x 50 × $6 \mathrm{~mm}$ MS "L" angle to fit the seed hopper and metering mechanism. A conveyor belt of $3555 \mathrm{~mm}$ was taken for preparing the grease belt. It was mounted on two rollers separated by a distance of $3235 \mathrm{~mm}$. The rollers were driven by one hp DC motor. The speed of the conveyor belt was controlled by a speed regulator of the variable speed drive. The motor of the hopper was driven by a $12 \mathrm{~V}$ DC battery power supply.

\section{Experimental procedure}

The experiments were carried out on maize seed. The rollers were driven by a one hp motor whose speed was varied to control the speed on grease belt. The speed of the conveyor belt was controlled by a speed regulator of the variable speed drive. The greased belt was driven at three speed levels of $1.5 \mathrm{~km} \mathrm{hr}^{-1}, 2 \mathrm{~km} \mathrm{hr}^{-1}$ and $3 \mathrm{~km} \mathrm{hr}^{-1}$.

The hopper motor was rotated at three levels of 20, 25 and $30 \mathrm{rpm}$. $\mathrm{COH} \mathrm{(M)} 6$ maize seed was graded on a sieve shaker to ensure the uniformity in size and filled in the seed hopper of the test rig. The grease coated belt was switched put 'ON' for rotation and the seed metering mechanism was actuated and seed were allowed to fall directly on the grease coated belt. The grease coated belt was run for its one complete rotation and both grease coated belt and the metering mechanism were stopped. The rpm of the hopper motor was controlled by the 12 V DC supply by varying the voltage. The seed to seed spacing was measured on the greased belt using a $3 \mathrm{~m}$ length steel rule. The experiment was replicated three times for each combination of selected variables.

\section{Results and Discussion}

The physical properties for maize $\mathrm{COH}(\mathrm{M}) 6$ is presented in table 1 . The mean dimensions of the maize seeds were 10.40, 9.24 and 5.4 $\mathrm{mm}$ in length, width and thickness, respectively, with sphericity as $77 \%$. These dimensions were taken into consideration for seed cells in metering roll. The average weight of one thousand maize seeds was $283.50 \mathrm{~g}$ with a bulk density of $0.81 \mathrm{~g} / \mathrm{cc}$. The angle of repose recorded for maize was 30 degree.

\section{Performance of metering mechanism on seed rate}

The increase in rotational speed from 20 to 30 rpm resulted in 9.4, 4.4 percent increase in seed rate at time interval of $20 \mathrm{sec}$ and $30 \mathrm{sec}$ of solenoid actuation respectively (Table 2). The effect of time interval of solenoid was negligible. 
Table.1 Seed properties of maize

\begin{tabular}{|c|c|c|}
\hline SI. No & Properties & Values $\pm \mathrm{SE}$ \\
\hline 1 & \multicolumn{2}{|l|}{ Physical dimensions } \\
\hline & a) Length, $\mathrm{mm}$ & $10.40 \pm 1.57$ \\
\hline & b) Width, mm & $9.24 \pm 1.2$ \\
\hline & c) Thickness, mm & $5.4 \pm 1.4$ \\
\hline 2 & Area, $\mathrm{mm}^{2}$ & $85.9 \pm 3.88$ \\
\hline 3 & Sphericity (\%) & $77 \pm 0.98$ \\
\hline 4 & Arthimetric mean diameter & $8.02 \pm 0.98$ \\
\hline 5 & Thousand seed weight & $283.5 \pm 1.45$ \\
\hline 6 & Bulk density & $0.81 \mathrm{~g} \mathrm{~cm}^{-3}$ \\
\hline 7 & Angle of repose & $30 \pm 0.98$ \\
\hline
\end{tabular}

Table.2 Effect of different operating speeds on seed rate of maize

\begin{tabular}{|c|c|c|c|}
\hline Forward speed & Motor rpm & Seed rate kg/ha & Recorded seed rate \\
\hline \multirow{3}{*}{$1.5 \mathrm{~km} \mathrm{hr}^{-1}$} & 20 & 18.32 & \multirow{3}{*}{20.81} \\
\hline & 25 & 20.05 & \\
\hline & 30 & 24.08 & \\
\hline \multirow{3}{*}{$2.0 \mathrm{~km} \mathrm{hr}^{-1}$} & 20 & 18.60 & \multirow{3}{*}{23.34} \\
\hline & 25 & 24.04 & \\
\hline & 30 & 27.40 & \\
\hline \multirow{3}{*}{$2.5 \mathrm{~km} \mathrm{hr}^{-1}$} & 20 & 21.36 & \multirow{3}{*}{24.34} \\
\hline & 25 & 24.89 & \\
\hline & 30 & 26.77 & \\
\hline
\end{tabular}

Table.3 Seed spacing uniformity of electronic metering mechanism for maize

\begin{tabular}{|l|l|c|c|}
\hline Forward speed & Replication & Average seed spacing & t-test \\
\hline \multirow{3}{*}{$\mathbf{1 . 5} \mathbf{~ k m / h r}$} & 1 & 25.50 & 1.23 (NS) \\
\hline & 2 & 26.20 & 1.93 (NS) \\
\hline & 3 & 27.00 & \\
\hline & Mean & 26.23 & \\
\hline & S.D & 1.53 & \\
\hline & CV (\%) & 0.76 & \\
\hline Deviation from recommended spacing(25 \\
cm)
\end{tabular}


Fig.1 Electronic metering unit

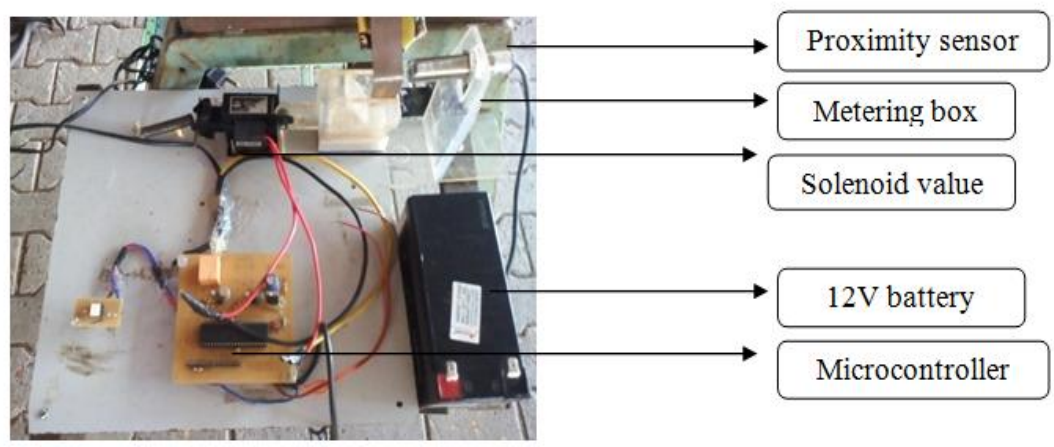

Fig.2 Flow diagram of metering unit

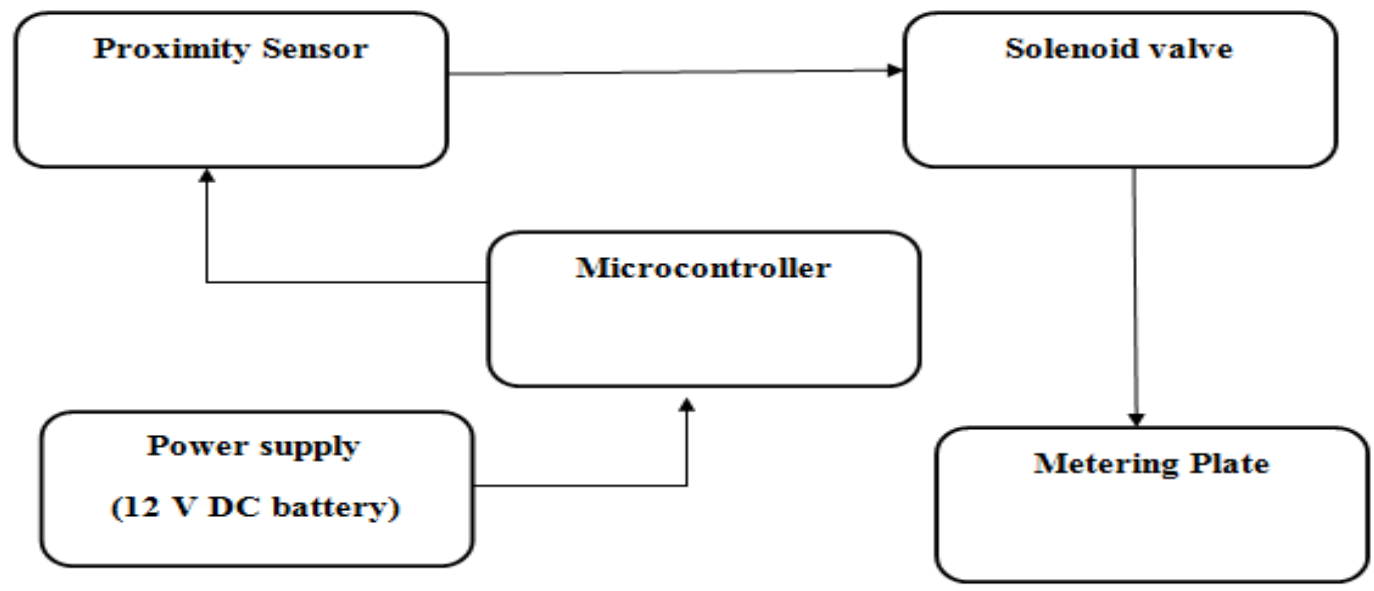

Fig.3 Circuit diagram of electronic metering unit

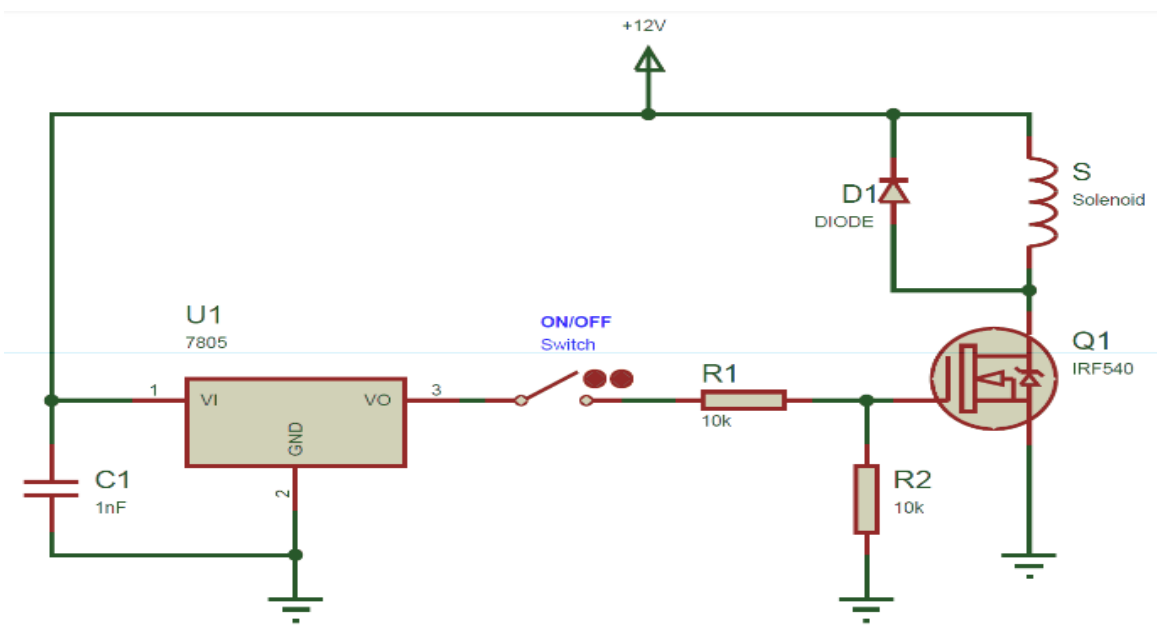


Fig.4 Hopper unit

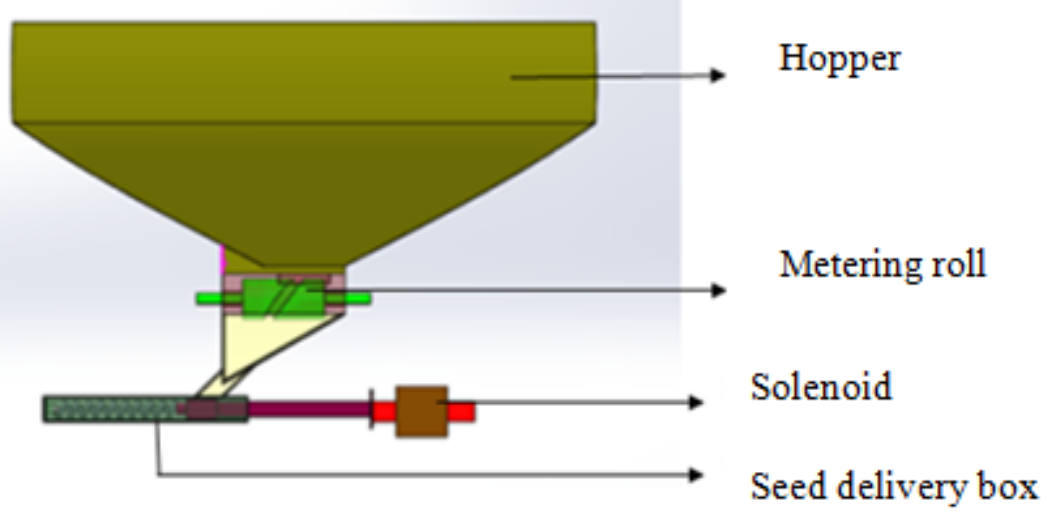

Fig.5 Top view of Test rig

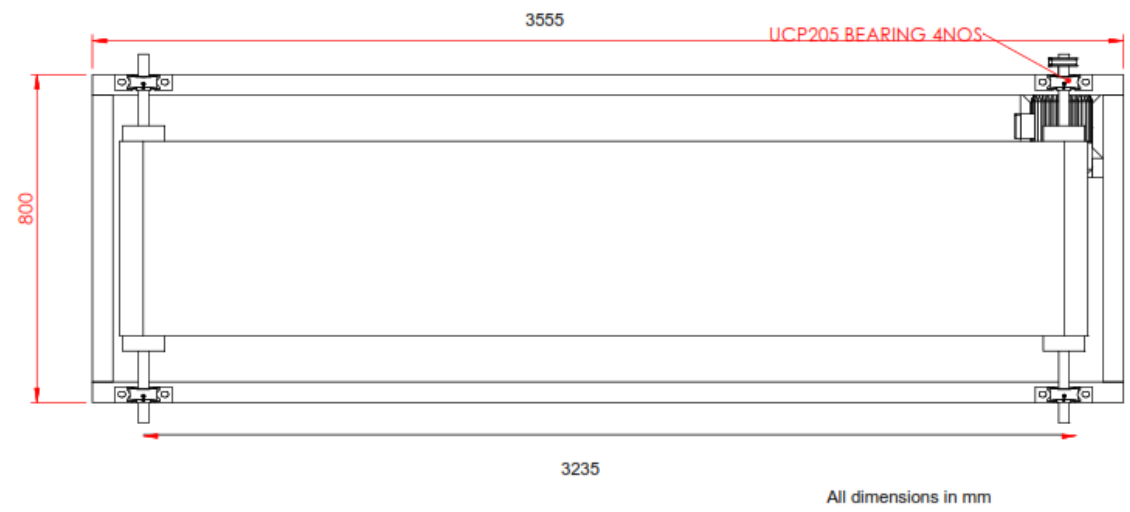

Fig.6 Electronic metering unit mounted on Test rig

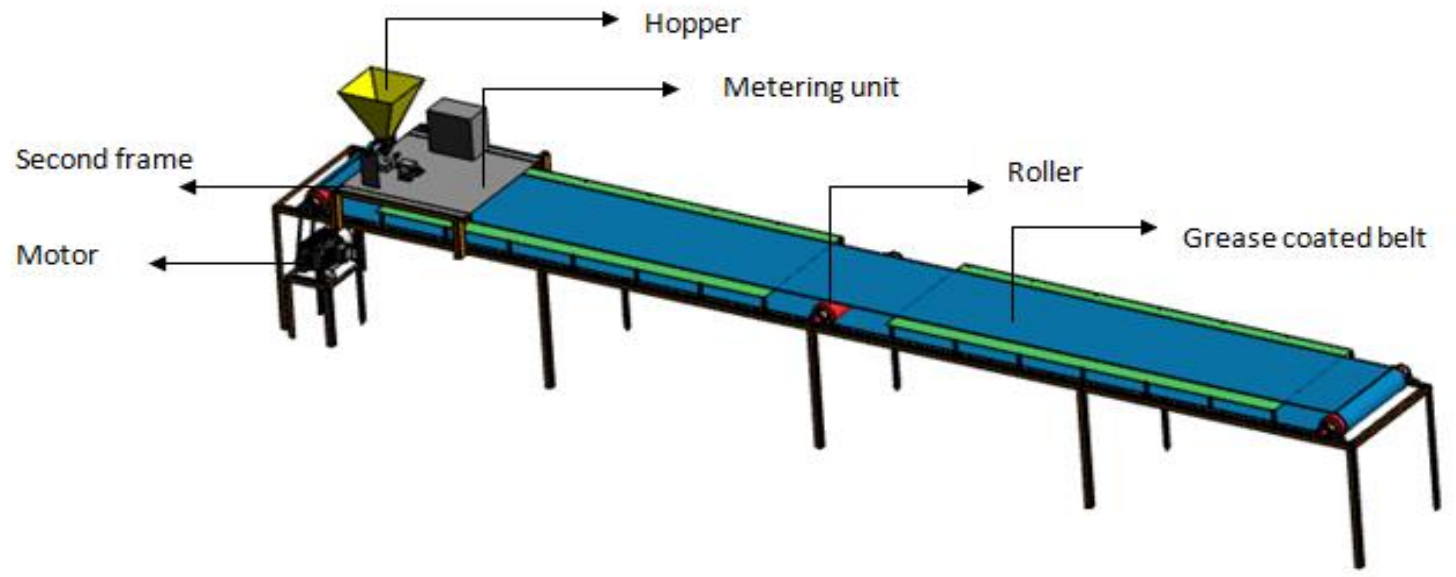


The combined effect of rotational speed and time interval of solenoid actuation on cell geometry $\mathrm{C}_{1}$ resulted in variation in seed rate from 17.10 to $18.56 \mathrm{~kg} / \mathrm{ha}$. The value is lower than the recommended seed rate of $20 \mathrm{~kg} / \mathrm{ha}$. The variation in seed rate was from 20.20 to $21 \mathrm{~kg} / \mathrm{ha}$ of cell geometry $\mathrm{C}_{2}$. The seed rate was vary from 22.00 to $22.96 \mathrm{~kg} / \mathrm{ha}$ on cell geometry $\mathrm{C}_{3}$ yielded greater than the recommended seed rate of $20 \mathrm{~kg} / \mathrm{ha}$. The rotational speed and time interval of solenoid actuation had a marginal effect on seed rate on cell geometry $\mathrm{C}_{2}$. The combination of all selected levels of rotational speed and actuation time of solenoid yielded almost the recommended seed rate of $20 \mathrm{~kg} / \mathrm{ha}$ on cell geometry $\mathrm{C}_{2}, 20 \mathrm{rpm} \mathrm{B}_{1}$ and 10 seconds solenoid actuation time $\mathrm{D}_{1}$. These findings are in close agreement with the results reported by Anantachar (2007) for peanut and chickpea varieties, Sahoo and Srivastava (2000) for okra seed.

\section{Performance on seed to seed spacing}

Increasing the rotational speed of stepper motor shows gradual increase in the value of mean seed spacing. The increase in rotational speed of seed metering roll from $20\left(\mathrm{~B}_{1}\right)$ to 25 rpm $\left(B_{2}\right)$ resulted in 13.3and 11.4 per cent increase in hill spacing. This might be due to the fact that rotational speed of metering roll has a direct influence on hill spacing. It is inferred that the spacing obtained in $20 \mathrm{rpm}$ of rotational speed of stepper motor were very nearer that of recommended seed spacing ( 25 $\mathrm{cm}$ ) for all levels of cell geometry and time of solenoid actuation. It is inferred that increase in cell geometry from $10 \mathrm{~mm}$ to $14 \mathrm{~mm}$ increased the seed spacing by 26.6, 20.9 and 24.3 per cent at rotational speed of 20,25 and $30 \mathrm{rpm}$, respectively (Table 3 ).

The seed spacing obtained at cell geometry $\left(\mathrm{C}_{3}\right)$ having cell size of $14 \mathrm{~mm}$ (i.e., 25 per cent more than maximum seed diameter) was higher followed by cell geometry $\mathrm{C}_{2}$ and $\mathrm{C}_{1}$ at all selected levels of rotational speed of stepper motor. This might be due to the fact that multiple seed occupied in the large size of cell $\mathrm{C}_{3}$ leading to occurrence of higher number of hills with multiple seeds and hence increased seed spacing.

The cell geometry with the occurrence of number of hills with no seed and multiple seeds was minimum with cell size $12 \mathrm{~mm}$ (10 percent more than the maximum seed diameter) with the desired seed spacing of 25 $\mathrm{cm}$, when compared to $\mathrm{C}_{1}$ and $\mathrm{C}_{3}$. Similar results were reported by Zelia and Aziz (2004) for maize varieties and Anantachar (2007) for chickpea and peanut varieties.

A experimental test rig was developed for electronic metering mechanism for maize and tested in the laboratory on grease coated belt. It results that increase in rpm of hopper motor at a constant forward speed of $1.5 \mathrm{~km} \mathrm{hr}^{-1}$ the seed to seed spacing decreased and vice versa.

\section{References}

Ag Leader seed command. http://www.agleader.com/ solutions/planting/. Accessed on [201311-21]

Anantachar, M., and Guruswamy, T. 2010. Neural network prediction of performance parameters of an inclined plate seed metering device and its reverse mapping for the determination of optimum design and operational parameters, Computers and Electronics in Agriculture, Vol. 72(2).

Jasa, P. J., 1981, Corn seed spacing uniformity in various tillage systems. M.S. thesis. Lincoln, Nebr.: University of Nebraska

John Deere planter brochure.
http://www.deere.com/en
US/products/equipment planting and 
seeding_equipment/planters/row_units/r ow. Emerge row unit plant seed hero. Accessed on [2014-06-12].

Kachman S D, Smith J A. Alternative measures of accuracy in plant spacing for planter using single seed metering. Transactions of the ASAE, 1995: 38, 379-387.

Kocher, M. F., Lan, Y., Chen, C. and Smith, J. A., 1998, Opto-electronic Sensor system for rapid Evaluation of Planter Seed Spacing uniformity. Trans. ASAE,
1998, Vol. 41, pp 237-245.

Moyer J R, Roman E S, Lindwall C W, Blackshaw R E. Weed management in conservation tillage systems for wheat production in North and South America. Crop Protection, 1994; 13(4): 243-259.

Raheman, H., and Singh, U. 2002. A sensor for seed flow from seed metering mechanism. Available at http://www.ieindia.org/pulbiah/ag/ 0603/june03ag2.pdf

\section{How to cite this article:}

Leela, C. and Saravanakumar, M. 2019. Development of Electronic Metering Experimental Test Rig for Maize. Int.J.Curr.Microbiol.App.Sci. 8(08): 1495-1502.

doi: https://doi.org/10.20546/ijcmas.2019.808.175 